\title{
Chemical composition of different formulations of bean (Phaseolus vulgaris L.) sarazo consumed in Sinaloa
}

\begin{abstract}
The consumption of dry common beans in Mexico has been modified by eating habits. The green bean seed or sarazo, is harvested When the seeds Have Reached Their maximum size but the seeds are not ripe, contributing to ancestral recipes That still prevail in Sinaloa. The objective was to evaluate the chemical composition of sarazo bean consumed in Sinaloa Formulations, as a value-added food alternative. Sarazo bean seeds (Azufrado Higuera) was used. The treatments were sarazo fresh beans (FC), cooked beans (FCO), cooked beans with vegetables at $4.6 \%$ (F1) and beans with $47 \%$ of vegetables and meat products (F2). The chemical composition was evaluated in triplicate with the standardized methods of the AOAC (2000). The experimental design was completely random, the analysis included a one-way ANOVA and Differences Between average values were evaluated With the Tukey $(p \leq 0.05)$ test. The results Showed That, in fat content, F2 Showed Differences $(p \leq 0.05)$ With respect to FC, FCO and F1, Caused by the Addition of fat include meat products in ITS That composition. In protein, FC showed no difference ( $p>0.05)$ With FCO, by heat treatment but the Addition of meat products had a significant Increase in F2. The heat treatment affected the soluble fiber. The cooking modifies the chemical composition; however, the main effect was the Addition of other components: such as vegetables and meat products. In protein, FC showed no difference ( $p>0.05)$ With FCO, by heat treatment but the Addition of meat products had a significant Increase in F2. The heat treatment affected the soluble fiber. The cooking modifies the chemical composition; however, the main effect was the Addition of other components: such as vegetables and meat products.
\end{abstract}

Volume 6 Issue 5 - 2019

\author{
Alma Lorena Urias Sauceda, Nora Estela \\ Ponce-Fernandez, Pollorena Gregorio- \\ Lopez, Cindy Rosas-Dominguez \\ Department of Engineering in Food Industry, Superior \\ Technological Institute of Guasave, Mexico
}

\begin{abstract}
Correspondence: Nora Estela Ponce Fernandez, Department of Engineering in Food Industry, Superior Technological Institute of Guasave, Mexico, Email nponcef.its@gmail.com
\end{abstract}

Received: August 19, 2019 | Published: September 17, 2019

Keywords: Phaseolus vulgaris L., sarazo bean, chemical composition, formulations

\section{Introduction}

The bean crop in Mexico is the main source of income in many regions, ${ }^{2}$ it is key in the national diet, it is considered a staple food, ${ }^{3}$ its consumption has been modified as a result of the change in eating habits, urban planning, employment and the search for food that provide health benefits. The bean stands out for its taste, high protein and natural carbohydrates; it is also abundant in vitamin B, provides iron, copper, zinc, phosphorus, potassium, magnesium, calcium and contains a high fiber. ${ }^{4}$ Mexico is the 7 th bean producer in the world; contributed $4 \%$ of world production and over 83 thousand 994 hectares in 2017, Sinaloa is the 2nd largest domestic producer, ${ }^{3}$ which is intended for consumption, decrease consumption and therefore only $3 \%$ of producers gives an added value most is marketed in bulk as dry $^{5}$ and to a lesser extent like a tender bean or sarazo, harvested when the seeds have reached their maximum size, are tender and the plant is green, ${ }^{6}$ so the planting cycle and the risk of damages for the drop in temperatures is reduced, however, respiration rate rises, difficult conservation, availability and consumption. ${ }^{7}$ According to a chain of regional news (2018), one of the attractions that draw visitors north of Sinaloa, it is gastronomy, by combining ancestral recipes that still prevail in the region. One of the typical dishes is the sarazo beans or cosahui, which is to process the tender beans, combined with vegetables and meat his research allows that by processing these ancestral recipes industrially, it helps to keep traditions, make them available to more people at any time of the year and contribute to regional development, promoting that Sinaloa ceases to be only a place of primary production, but to become a food industrializing state. That's what the objective is to evaluate the chemical composition of formulations sarazo beans consumed in Sinaloa, as an alternative to market value-added grain and processed food ready for consumption and available all year.

\section{Materials and methods}

\section{Formulations}

\section{Sarazo bean}

Sarazo beans (Phaseolus Vulgaris L), Azufrado Higuera variety, obtained in the region of Guasave, Sinaloa, 2017-2018 cycle, collected randomly, 15 weeks from planting used. The beans were processed in the Laboratory of Food Technology and Biochemistry and Microbiology Higher Technological Institute of Guasave. Treatments were fresh bean sarazo (FC), cooked beans sarazo (FCO), bean vegetable mixture added with $4.6 \%$ (F1) and beans supplemented with vegetables and meat products mixture $47 \%$ (F2). Treatment involves removal FC bean pod directly. To $100 \mathrm{~g}$ FCO bean were soaked for 30 min weighed, drained and cooked under boiled water for 30 minutes. The samples were cooled and refrigerated for 24 hours at $4^{\circ} \mathrm{C}$ before analysis. For F1, a mixture of vegetable (tomato, peppers and onions) 
were added after which repeat the procedure performed for FCO was performed. And finally F2, consisted in repeating the procedure F1 and add a mixture of meat products (sausage, sausage, ham and bacon) $47 \%$.

\section{Chemical composition}

Moisture, fat, protein, fiber and minerals bean formulations were evaluated in triplicate with the standardized AOAC. ${ }^{1}$ Moisture was determined using AOAC 4.1.03 (2000) method 934.01 in an oven (Yamato DNE400) at $100^{\circ} \mathrm{C}$ for at least $8 \mathrm{~h}$. The dry matter content was calculated by difference, subtracting $100 \%$ humidity. Quantification of fat, was performed as indicated AOAC 4.1.05 (2000) Method 920.39, on the free moisture sample in Soxhlet extraction equipment. Protein content was determined on the dry fat-free sample, according to the AOAC 12.1.07 (2000) Method 960.52, using a microKjeldahl (Scorpion Scientific A50304, Mexico) equipment. For calculations 6.25 was used as protein conversion factor. The percentage of fiber was determined by AOAC method 962.09 of (2000), using an extractor fiber (A-50290 Scorpion Scientific). The minerals were quantified by the AOAC (2000) Method 942.05, using a muffle (Felisa FE-363) at $550^{\circ} \mathrm{C}$ for at least $4 \mathrm{~h}$. And the carbohydrate content was calculated by difference.

Table I Chemical composition of the formulations bean sarazo a,b,c,d literal different within column indicates significant difference ( $p \leq 0.05)$

\begin{tabular}{llllll}
\hline Treatment & Dry material & Grease* & Protein* & Fiber* & Minerals \\
\hline FC & $57.97 \pm 0.79 \mathrm{a}$ & $2.17 \pm 0.12 \mathrm{~b}$ & $18.06 \pm 0.04 \mathrm{c}$ & $8.25 \pm 1.06 \mathrm{~b}$ & $5.01 \pm 0.12 \mathrm{~A}$ \\
FCO & $43.23 \pm 1.66 \mathrm{~b}$ & $0.68 \pm 0.2 \mathrm{Ib}$ & $18.02 \pm 0.07 \mathrm{c}$ & $3.10 \pm 0.4 \mathrm{Ic}$ & $4.73 \pm 0.37 \mathrm{a}$ \\
FI & $18.52 \pm 0.86 \mathrm{~d}$ & $1.02 \pm 0.05 \mathrm{~b}$ & $25.92 \pm 0.98 \mathrm{~b}$ & $14.79 \pm 0.37 \mathrm{a}$ & $8.69 \pm 0.49 \mathrm{~b}$ \\
F2 & $23.91 \pm 0.35 \mathrm{c}$ & $16.73 \pm 1.15 \mathrm{a}$ & $37.53 \pm 0.60 \mathrm{a}$ & $13.42 \pm 0.12 \mathrm{~A}$ & $7.76 \pm 0.59 \mathrm{c}$ \\
\hline
\end{tabular}

*Results reported on a dry basis $\mathrm{g} / \mathrm{l} 00 \mathrm{~g} \pm \mathrm{SD}(\mathrm{n}=3)$.

Protein, FC showed no significant difference ( $p>0.05)$ with FCO, which coincide with those reported by Silva-Cristobal et al., ${ }^{10}$ in black bean, is less than $27.8 \%$ and $20.4 \%$, mentioned Telles et al., ${ }^{11}$ and Sanchez-Arteaga et al., ${ }^{12}$ which is attributed to shorter maturity of the beans. FC, FCO and F1 are within the $14-33 \%$ protein mentioned Ulloa et al., ${ }^{9}$ Adding meat products affected the protein significant increase in F2. The fiber content was affected by treatments. FC is slightly lower than $11.35 \%$ shown by Fernandez \& Sanchez ${ }^{13}$ in bean seed. FCO decreased over FC ( $\mathrm{p} \leq 0.05)$, is attributed to the cooking process solubilized fiber, according Jacinto \& Fields ${ }^{14}$ the raw beans has more fiber than was subjected to a treatment cooking. Most fiber was made in F1, F2 followed by no difference ( $>>0.05)$ due to the addition of vegetables in the formulation.

In the mineral content, significant differences due to the treatments were presented. FC minerals and FCO ( $>00.05)$ match that shown by Sanchez-Arteaga et al., ${ }^{12}$ for sulfur and bean Rezende et al., ${ }^{15}$ in 8 different bean varieties with values of 3-4\%.; and it is lower than found by Fernandez \& Sanchez ${ }^{13}$ in seed string beans. F1 and F2 were significantly different $(\mathrm{p} \leq 0.05)$ to $\mathrm{FC}$ and $\mathrm{FCO}$, since the mineral content was higher, which was attributed to the addition of vegetables and meat products. ${ }^{16}$

\section{Conclusions}

Because the sarazo bean harvested at the end of its growth cycle, fresh grains are, therefore, its characteristics are different from a commercial bean (dry), mainly by the higher moisture content. The content of protein, fat and minerals are not affected by the state of

\section{Statistical analysis}

The experimental design was completely random, the treatments were the formulations (FC, FCO, F1 and F2), in triplicate and the data obtained were evaluated with a one-way ANOVA (Minitab 16). Differences between means were evaluated by multiple range test of Tukey with a confidence level of $95 \%$.

\section{Results and discussion}

The chemical composition (Table 1) showed that the dry matter content, present significant $(\mathrm{p} \leq 0.05)$ in the four treatments, mainly because treatments. According to the technique Agenda, ${ }^{8}$ the moisture content recommended for harvest of dry beans is 14 to $16 \%$, indicating that sarazo beans, although their grains have reached the larger content humidity is high, so that the cycle time would be less. In the fat content, the results coincide with those reported by Ulloa et al., ${ }^{9}$ in 2011, who report that the corresponding lipid fraction is 1.5-6.2 $\mathrm{g} / 100 \mathrm{~g}$, where, although FCO is below, it has no significant difference with FC and F1 ( $p>0.05)$. F2 showed differences $(p \leq 0.05)$ about FC, FCO and F1, caused by the addition of meat products include fat composition. 
4. Sangerman-Jarquin DM. Acosta-Gallegos JA, Sohwenstesius RR, et al. Considerations and social importance around the cultivation of beans in central Mexico. Agricultural Sciences. 2010;1 (3):363-380.

5. Saldaña MR. Bean, rich source of protein. CONABIO Biodiversitas. 2010;89:7-11

6. Ancín RM. Evaluation of different types of chemical and organic fertilizers in bean production (Phaseolus Vulgaris L. Var. Alubia) in the district of San Juan de Castrovirreyna-Huancavelica (Peru) (undergraduate thesis). Public University of Navarra, Peru; 2011.

7. Lara FM. The cultivation of beans in Mexico. University digital magazine. 2015;16(2)2-11.

8. INIFAP (National Institute of Forestry, Agricultural and Livestock Research). Sinaloa Agricultural Technical Agenda; 2017.

9. Ulloa JA, Rosas UP, Ramírez-Ramírez JC. Beans (Phaseolus vulgaris): their nutritional importance and as a source of phytochemicals. Source Magazine. 2011.

10. Silva-Cristobal L, Osorio-Díaz P, Tovar J, et al. Chemical composition, carbohydrate digestibility, and antioxidant capacity of cooked Mexican varieties of black beans, chickpea, and lentil. Cyta - Journal of Food. 2010;8(1):7-14.

11. Telles AC, Kupski L, Furlong EB. Phenolic compound in beans as protection against mycotoxins. Food Chem. 2017;214:293-299.

12. Sánchez-Arteaga HM, Urías-Silvas JE, Espinosa-Andrews $\mathrm{H}$, et al Effect of chemical composition and thermal properties on the cooking quality of common beans (Phaseolus vulgaris). Cyta Journal of Food. 2015;13(3):385-391.

13. Fernández FVAF, Sánchez CE. Study of the physicochemical properties and nutritional quality in different bean varieties consumed in Mexico. Nova Scientia. 2007;9(1):133-148.

14. Jacinto HC, Campos EA. Effect of cooking on some nutritional characteristics of beans. Mesoamerican Agronomy. 1993;4:42-47.

15. Rezende AA, Pacheco MTB, Silva VSND, et al. Nutritional and protein quality of dry Brazilian beans (Phaseolus vulgaris L.). Food Science and Technology. 2018;38(3):421-427.

16. Meganoticias. Villa of Ahome towards magical town. Mega news. The Mochis Sinaloa; 2018. 